\title{
CSAE WPS/2010-25
}

\author{
Higher Education and Economic Development in Africa: \\ a Review of Channels and Interactions ${ }^{(a)}$
}

Francis Teal

Centre for the Study of African Economies

University of Oxford

August 2010

\begin{abstract}
While the numbers with completed tertiary level education are low in Africa, both relative to other countries and in absolute terms, they have been growing very rapidly. Three questions are addressed in this paper. The first is how higher education links to other forms of capital accumulation in a process that leads to economic growth. The second is how higher education links to job outcomes in particular the role of the public sector and self-employment as outcomes for graduates. The third is whether and how an expansion of skilled jobs can create its own demand. The paper draws on both macro and micro evidence to answer those questions which are placed in a long run historical context. It is argued that growth has been more closely linked to investment in physical capital than in education and this may well reflect the fact that education is most valuable when it is linked to technology which requires higher skills. Data from thirty two African countries are used to show that the returns to education, measured both by macro production functions and by micro earning functions, are highest for those with higher levels of education. A contrast is drawn between the role of higher education in providing access to public sector employment and the increasing importance of self-employment in Africa. The paper concludes by asking whether Africa can use its investment in higher skilled labour to effect a service based growth revolution.
\end{abstract}

\footnotetext{
(a) This is a substantially revised version of a paper prepared for a Plenary Session on: Higher Education and Economic Development at the AERC Biannual Research Workshop May 29 - June 3, 2010, Mombasa Kenya. I am indebted to participants at that workshop for comments. Markus Eberhardt has been very generous with his time in assisting me in preparing and interpreting the data presented in this version of the paper. This paper draws on educational research undertaken as part of the Research Consortium on Educational Outcomes and Poverty (RECOUP) funded by DfID. The research on labour market outcomes, on which the paper draws, was funded in part by an IDRC project on the impact of skills on job creation and poverty in sub-Saharan Africa and in part by an ESRC funded project on informality and finance in Africa.
} 


\section{Introduction}

Figure 1 shows the evolution of GDP for five non-African countries - the US, UK, Brazil, China and India - over the period from 1500 to 2000 and one African country - Ghana - over the period since 1870. I choose these countries for three reasons as an introduction to a paper concerned with higher education and economic development in Africa. The first is to provide a context for the recent acceleration in Africa's growth rate. The second as an introduction to the argument that the links between human capital formation - of which higher education is one part - are complex and unlikely to be invariant to the period of growth we wish to understand. The third is as a prelude to the final part of this paper which will ask whether all countries need to climb similar mountains or whether alternative paths are possible.

Figure 1 Growth in Historical Perspective

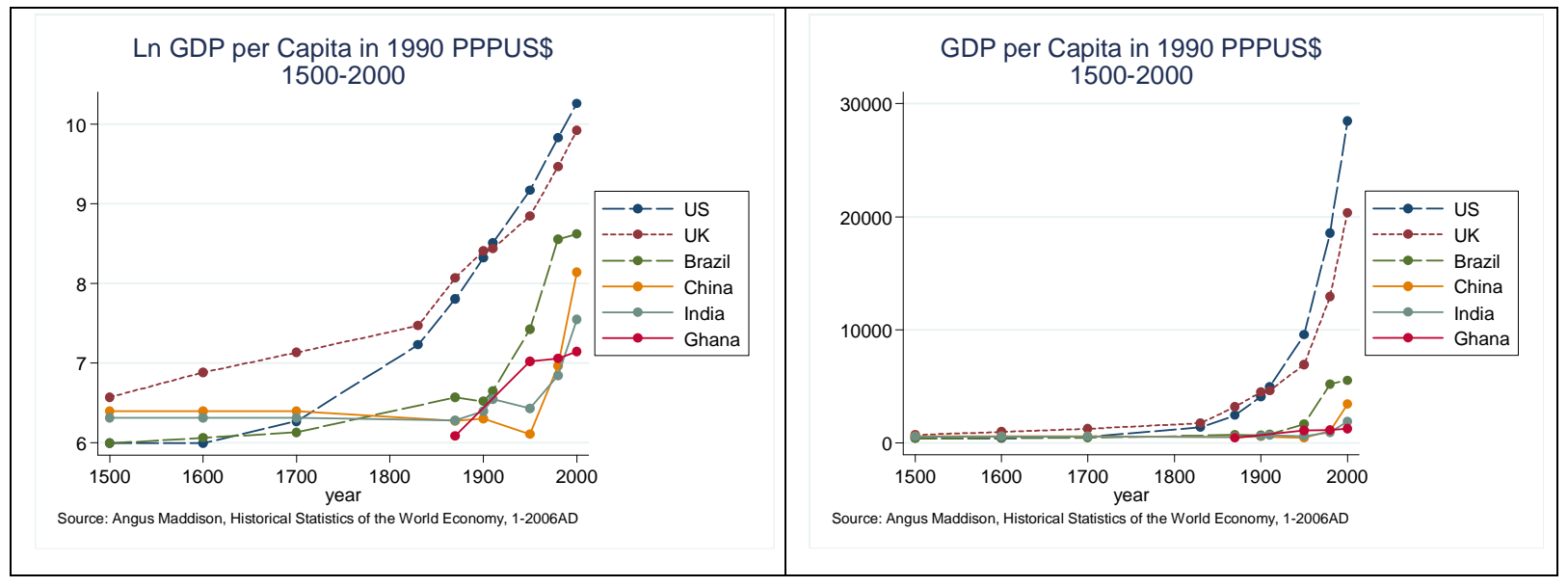

Figure 2 African GDP in Perspective

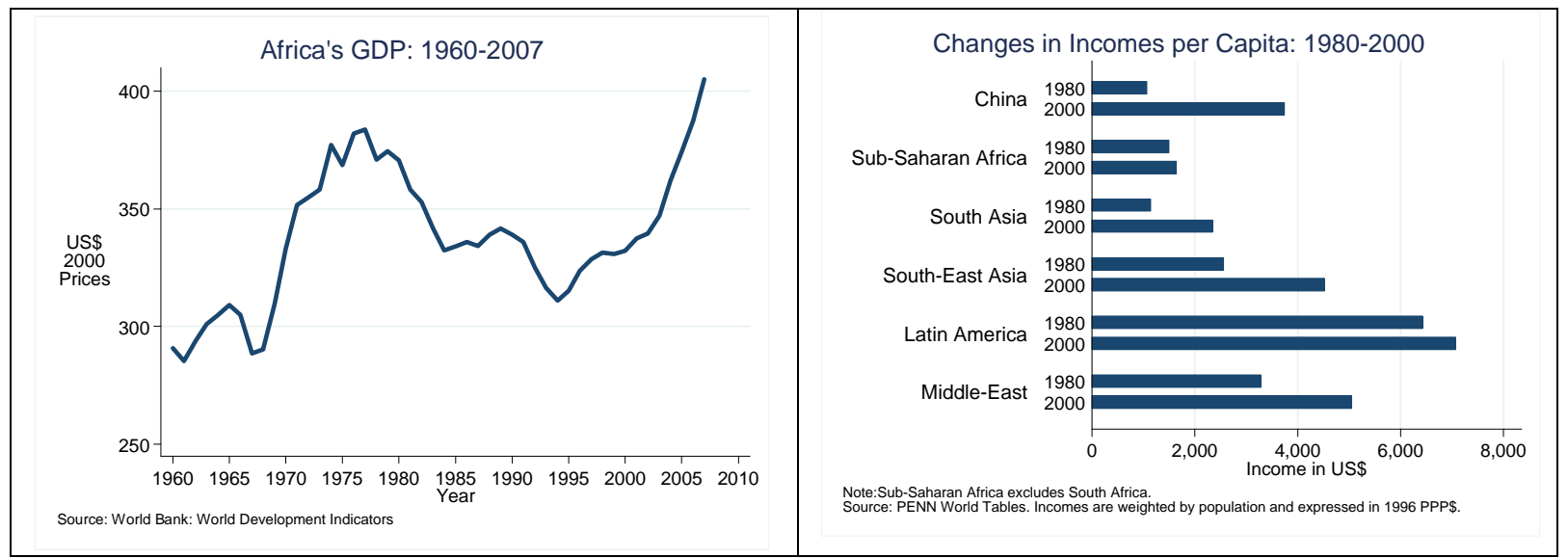

Why is the historical pattern of growth a vital part of understanding the context for African development today? Economic development is a relatively recent historical phenomenon. In both the UK and the US it clearly accelerated in the early part of the nineteenth century. In two of the countries, Brazil and Ghana, it accelerated at the end of the nineteenth century. In India and China the acceleration was very much more recent dating from after 1980. Not only are these countries much later but in the case of China the growth rates are historically at an unprecedented rate. The reason there is only one Africa country on the chart is that, with the exception of South Africa, Ghana is the 
only sub-Saharan country for which we have comparative data from Maddison (2006) before 1950. Figure 2 shows African growth in much more recent historical perspective. Focusing on the period since 1980 we see a picture which will be familiar. Africa experienced a sustained fall in income from the mid 1970s until the 1990s and then a relatively rapid recovery. However as the chart to the right of Figure 2 shows this period of fall and rise saw the take off of the Chinese and Indian economies. Both countries went from being poorer than Africa to being richer and growing at much faster rates. Thus we have the central question posed by this paper: what underlies the acceleration of the growth rate in other parts of the developing world, can Africa follow and what will be the role of education in this process?

So what has been the role of human capital generally and expenditure on higher education specifically in the growth paths we have observed? That is clearly a question that has been very widely posed and in Section 2 I want to review some of the macro evidence and in Section 3 that based on micro studies. Traditionally education in Africa has been a path to public sector employment. The implications of that path for higher education will be the subject of Section 4. In the paper it will be argued that there is a tension between two roles that higher education plays. The first is a conduit of knowledge, the second as a path to public sector employment. How, and whether, they can be reconciled and linked to a process of economic development is the subject of Section 5 which acts to introduce the speculative part of the paper. China's growth has shown an ability to grow at rates previously thought impossible, can Africa emulate this and, if so, will it be by a very different path to that followed by China and what role will education generally, and higher education in particular, play in this process?

\section{How does human capital link to other forms of capital: the macro empirical evidence}

The key role of the increase in knowledge and the human capital which has built that knowledge in explaining how sustained rises in per capita income have been possible since the nineteenth century is not in doubt. What is in doubt, and the subject of substantial disagreement, is how education impacts on this growth process. In this section we will review some of that evidence and suggest why the link between investment in human capital and growth is much less direct than one might at first believe.

The data we have presented in Figure 1 shows the long sweep of economic history dating back to 1500. We do not have comparative education data going back so far. However due to the work of Barro and Lee (2010) we do have comparative data from 1950 to 2010 so we can put human capital accumulation in Africa in a comparative context over that more recent period and we can seek to understand its possible role in the very recent accelerations in growth rates which have occurred in China and India but not in Africa. Table 1(a) is taken from Barro and Lee (2010) which updates their previous data shows how the average level of education in Africa has grown relatively to the rest of the world. Table 1(b) shows how the percentage in higher education has also changed. Both Tables refer to the total population in the country aged over 15 to exclude those currently in school. What Table 1 shows is that education in Africa has been rising as fast, or faster, than in other countries. From 1950 to 2010 the average years of education in Africa increased by a factor of 4 times from 1.3 to 5.2 years of education. This is higher than the average for all developing countries (their average rose 3.5 times) and much higher than the rise for advanced countries (their average rose by 1.8 times). It is also true that in terms of growth rates the increase in those with completed tertiary education has been as high in Africa as it has in other developing countries and the rise has been truly enormous. Between 1950 and 2010 the percentage of the population with tertiary completed education has increased in developing countries, including Africa, by a factor of 10 . 
Table 1(a) Average Years of Schooling of the Total Population Aged 15 and Over

\begin{tabular}{ccccc}
\hline & World & Advanced & Developing & $\begin{array}{c}\text { Sub-Saharan } \\
\text { Africa }\end{array}$ \\
\hline & $(146)$ & $(24)$ & $(122)$ & $(33)$ \\
1950 & 3.2 & 6.2 & 2.1 & 1.3 \\
1960 & 3.7 & 6.8 & 2.6 & 1.5 \\
1970 & 4.5 & 7.7 & 3.4 & 2.0 \\
1980 & 5.3 & 8.8 & 4.3 & 2.8 \\
1990 & 6.1 & 9.6 & 5.2 & 3.9 \\
2000 & 7.0 & 10.7 & 6.2 & 4.6 \\
2010 & 7.8 & 11.0 & 7.1 & 5.2 \\
\hline
\end{tabular}

Table 1(b) Percentage with Tertiary Education Completed of the Total Population Aged 15 and Over

\begin{tabular}{ccccc}
\hline & World & Advanced & Developing & $\begin{array}{c}\text { Sub-Saharan } \\
\text { Africa }\end{array}$ \\
\hline & $(146)$ & $(24)$ & $(122)$ & $(33)$ \\
1950 & 1.1 & 2.8 & 0.5 & 0.1 \\
1960 & 1.4 & 3.5 & 0.7 & 0.2 \\
1970 & 2.0 & 5.1 & 1.0 & 0.2 \\
1980 & 3.1 & 8.3 & 1.6 & 0.3 \\
1990 & 4.4 & 11.6 & 2.6 & 0.5 \\
2000 & 5.9 & 15.4 & 3.8 & 0.7 \\
2010 & 6.7 & 14.5 & 5.1 & 0.9 \\
\hline
\end{tabular}

Source: Barro and Lee (2010). The figures in ( ) parentheses are the number of countries included in the data.

These rapid growth rates reflect in part the very low levels of education in Africa at the start of the period. It is also true the levels with a tertiary education in Africa remain very low, just under 1 per cent of the population aged over 15 which remains far below the level of Asia and other developing areas. These basic facts suggest two questions. First, how can we reconcile the high growth rates of education in Africa with its low growth rate in incomes? Second, do the low levels of education in Africa, particularly at the higher level, limit Africa's ability to initiate the kind of growth accelerations we have seen in other countries?

Prichett (2001, 2006) draws attention to the fact that while the micro relationship between earnings and education is one of the most robust empirical relationships in economics the same is not true at the macro level. The relationship between aggregate levels of education and growth or GDP has been investigated primarily in the context of the empirical Solow model set out in a very influential paper by Mankiw, Romer and Weil (1992). A major divide in the empirical implementation of this model is whether identification is obtained by exploiting the cross-section or the time series aspects of the data. Broadly speaking those who use the cross section variation in the data find highly significant and substantial effects from human capital on income while those who exploit the time series of the data, find as in Prichett $(2001,2006)$ that changes in income are not at all closely related to changes in education.

What might account for this difference between cross-section and time series findings? There are, at least, three possible sources for this divergence. The first is that the cross section relationship is due not to any causality from education onto income but that both are driven by some common timeinvariant factor which is removed once the data is differenced. The second is that education is measured very poorly and that differencing the data enhances that measurement error making it 
difficult or impossible to find a relationship between changes in education and changes in income (see Krueger and Lundahl (2001)). The third is that with a short panel it is difficult to capture both the time-invariant and dynamic aspects of a specification such as has been attempted by the approach pioneered by Mankiw, Romer and Weil (1992). Their framework begins with a standard CobbDouglas production function in which human as well as physical capital is incorporated.

$$
V_{i t}=K_{i t}^{\alpha} H_{i t}^{\beta}\left(A_{i t} L_{i t}\right)^{(1-\alpha-\beta)} e^{u_{i t}}
$$

where $K_{i t}$ is physical capital, $H_{i t}$ is human capital, $L_{i t}$ is the labour force and $A_{i t}$ is total factor productivity (TFP) which is assumed to be labour augmenting. In empirical implementation of this model various proxies for human capital are used. A specification that underlies the macro growth accounting exercise of Hall and Jones (1999) is of the following form:

$$
H_{i t}=e^{\phi\left(E_{i t}\right)} L_{i t}
$$

where $E_{i t}$ is the years of education of the workforce. This definition of human capital has the advantage that it can be explicitly linked to the form of the Mincerian earnings function used in micro studies of the return to education. If we are willing to make an explicit assumption as to the form of the function linking education to human capital $\phi\left(E_{i t}\right)$ as in:

$$
\phi\left(E_{i t}\right)=\delta_{0}+\delta_{1} E_{i t}+\delta_{2} E_{i t}^{2}+v_{i t}
$$

Then we can write the value of human capital as:

$$
w_{H} H_{i t}=w_{H} e^{\phi\left(E_{i t}\right)} L_{i t}=w_{L(i t)} L_{i t}
$$

where $w_{H}$ is the price of human capital and $w_{L}$ the price of labour and derive the Mincerian earnings function in this macro context which we will meet again when we come to the micro evidence:

$$
L n w_{L_{(i t)}}=\delta_{0}+\delta_{1} E_{i t}+\delta_{2} E_{i t}^{2}+v_{i t}
$$

As at the macro level wage data is not available (or at least not used) testing the model involves either calibration or the estimation of the production function set out above or, by following the approach pioneered by Mankiw, Romer and Weil (1992), estimating a convergence equation of the form:

$$
\begin{aligned}
& \operatorname{Ln} \frac{V}{L i, t+1}-\operatorname{Ln} \frac{V}{L_{i, t}}=-\rho \ln \frac{V}{L_{t}} \\
& \left.+\rho\left(\frac{\alpha+\beta}{1-\alpha-\beta} \operatorname{Ln}(n+g+\delta)+\frac{\alpha}{1-\alpha-\beta} \operatorname{Lns}_{i t}^{k}+\frac{\beta}{1-\alpha-\beta} \operatorname{Ln} s_{i t}^{h}\right)\right)+\rho(A(0)+g t)+g
\end{aligned}
$$

where $n$ is the rate of population growth, $g$ the rate of technical progress and $\delta$ the rate of depreciation, $s_{i t}^{k}$ the rate of saving of physical capital and $s_{i t}^{h}$ the rate of saving of human capital. In this equation it can be shown that where $\left(1-e^{\lambda}\right)=\rho$ then $\lambda=(n+g+\delta)(1-\alpha)$ is the rate of convergence. 
Bloom, Canning and Chan (2005) specifically address the role of higher education in Africa using this conditional convergence specification. They argue that there is some evidence that tertiary education raises the rate of technological convergence once instruments are used. Gyimah-Brempong, Paddison and Mitiku (2006) also investigate the role of tertiary education in Africa and report results of a convergence specification using instruments but now being explicit that the dynamic specification requires a GMM estimator. They find very large effects from higher education onto growth once they instrument.

In contrast to these empirical models is an approach to assessing the role of human capital which calibrates macro models. As they wish to link the Mincerian earnings function to the value of human capital Hall and Jones (1999) simplify the production function to the following two factor form where technical progress is now assumed to be human capital augmenting:

$$
V_{i t}=K_{i t}^{\alpha}\left(A_{i t} H_{i t}\right)^{(1-\alpha)} e^{u_{i t}}
$$

which leads to an estimatable production function of the form:

$$
\operatorname{Ln} \frac{V_{i t}}{L_{i t}}=\alpha \operatorname{Ln} \frac{K_{i t}}{L_{i t}}+(1-\alpha) \operatorname{Ln} A_{i t}+(1-\alpha) \phi\left(E_{i t}\right)+u_{i t}
$$

This simplifed form of the production function ensures that with an assumption about the Mincerian return to education, which is defined as $\phi^{\prime}\left(E_{i t}\right)$, it is possible to decompose productivity differences across countries into those due to human capital, those due to differences in the capital output ratio, and a residual which is underlying differences in TFP. Hall and Jones (1999) use this framework and find that human capital can explain relatively little of the large productivity differentials across countries. The assumptions underlying this exercise are implicit in the above model namely that technical progress is human capital enhancing and, which is crucial, that different levels of education are perfect substitutes. Caselli and Coleman (2006) relax this last assumption and calibrate a macro model with imperfect substitutability between skilled and unskilled labour. They argue that the efficiency with which skilled labour is used increases with the level of income and this can fully explain differences in labour productivity across countries. In other words they reverse the Hall and Jones (1999) conclusion. Differences in income are not due to TFP they are due to differences in the efficiency with which skilled labour is used which is clearly open to the interpretation that it is the efficiency with which education impacts of labour efficiency which is crucial for understanding differences in per capita incomes.

In Table 2 ordinary least squares (OLS), fixed effects (FE) and first differenced (FD) estimates of the following two production functions are presented for 32 African countries (given in Appendix 1):

$$
\begin{gathered}
\operatorname{Ln} \frac{V_{i t}}{L_{i t}}=\alpha \operatorname{Ln} \frac{K_{i t}}{L_{i t}}+(1-\alpha) \operatorname{Ln} A_{i t}+(1-\alpha)\left[\delta_{1} y r s_{s c h}\right]+u_{i t} \\
\operatorname{Ln} \frac{V_{i t}}{L_{i t}}=\alpha \operatorname{Ln} \frac{K_{i t}}{L_{i t}}+(1-\alpha) \operatorname{Ln} A_{i t}+(1-\alpha)\left[\delta_{1} y r s_{p r i}+\delta_{2} y r s_{s e c}+\delta_{3} y r s_{t e r}\right]+u_{i t}
\end{gathered}
$$

The first of these is is of the same form as that implicitly used by Hall and Jones (1999) where $y r s_{s c h}$ is the average years of education for the country. The second extends the specification so that primary, secondary and tertiary education are separately identified. In linking these empirical 
Table 2 Dependent Variable Ln (Real GDP) for sub-Saharan African Countries ${ }^{(a)}$

\begin{tabular}{|c|c|c|c|c|c|c|}
\hline & OLS & OLS & $\mathrm{FE}$ & $\mathrm{FE}$ & FD & FD \\
\hline & [1] & [2] & [3] & [4] & [5] & [6] \\
\hline \multirow[t]{2}{*}{ Ln (Population) } & 0.44 & 0.54 & 0.17 & 0.3 & 0.39 & 0.44 \\
\hline & {$[12.07]^{* * *}$} & {$[14.74]^{* * *}$} & [0.49] & [1.00] & {$[1.71]^{*}$} & {$[1.94]^{*}$} \\
\hline \multirow[t]{2}{*}{ Ln (Capital stock) $)^{(\mathrm{b})}$} & 0.52 & 0.45 & 0.74 & 0.75 & 0.54 & 0.54 \\
\hline & {$[13.47]^{* * *}$} & {$[11.97]^{* * *}$} & {$[8.44]^{* * *}$} & {$[9.28]^{* * *}$} & {$[9.81]^{* * *}$} & {$[9.65]^{* * *}$} \\
\hline \multirow[t]{2}{*}{ Yr_sch ${ }^{(c)}$} & 0.08 & & 0.07 & & 0.05 & \\
\hline & {$[3.77]^{* * *}$} & & {$[1.86]^{*}$} & & [1.54] & \\
\hline \multirow[t]{2}{*}{ Yr_sch_pri } & & 0.01 & & -0.02 & & -0.03 \\
\hline & & [0.27] & & [0.41] & & {$[0.63]$} \\
\hline \multirow[t]{2}{*}{ Yr_sch_sec } & & 0.19 & & 0.22 & & 0.15 \\
\hline & & {$[2.96]^{* * *}$} & & {$[2.53]^{* *}$} & & {$[1.70]^{*}$} \\
\hline \multirow[t]{2}{*}{ Yr_sch_ter } & & 4.31 & & -1.05 & & 0.21 \\
\hline & & {$[4.22]^{* * *}$} & & {$[1.20]$} & & {$[0.26]$} \\
\hline \multirow[t]{2}{*}{ Constant } & 3.93 & 4.1 & 2.99 & 0.99 & 0 & 0 \\
\hline & {$[7.35]^{* * *}$} & {$[8.27] * * *$} & {$[0.61]$} & {$[0.25]$} & {$[0.04]$} & {$[0.12]$} \\
\hline Observations & 280 & 280 & 280 & 280 & 257 & 257 \\
\hline R-squared & 0.88 & 0.89 & 0.9 & 0.91 & 0.4 & 0.41 \\
\hline \multicolumn{7}{|c|}{ Robust t statistics in brackets: * significant at $10 \%$; ** significant at $5 \%$; *** significant at $1 \%$} \\
\hline \multicolumn{3}{|l|}{ Number of countries } & 32 & 32 & & \\
\hline
\end{tabular}

(a) The measure of GDP is taken from the PENN World Tables 6.3 and uses 'rgdpl' which is "Real GDP per capita (Constant Prices: Laspeyres), derived from growth rates of c, g, i in 2005 constant US prices". This per capita number is multiplied by population to get GDP. The countries included in the sample are given in Appendix 1.

(b) The capital stock has been accumulated from the investment data by the methods used by Klenow and Rodríguez-Clare (1997). See Appendix 2 for details.

(c) Yr_sch is the years of education Yr_sch_pri is the years of primary education, Yr_sch_sec is the years of secondary education and $\mathrm{Yr} \_$sch_ter is the years of tertiary education, all for the population aged over 15, from Barro and Lee (2010).

The sample uses data from 1960 to 2004. The income and capital data is averaged over five year periods from 1960-1964 to 2000-2004 inclusive, making a panel data set of nine periods across 32 countries. The education data is available only every five years and the data used for the period 1960-1964 is the years of education for 1960 etc.

Summary statistics are given in Appendix 3 with details of the sample.

estimates to the assumptions underlying the macro calibration exercises two points stand out. The first is that the point estimate on capital of 0.45 in the OLS (it is higher for the FE and FD estimators) far exceeds the value of 0.3 assumed in the calibration exercises. The second is that there is clear evidence that the returns to education are convex not concave as is assumed in the calibration excercises of Hall and Jones (1999) and Caselli and Coleman (2006). The OLS results give higher returns for secondary than for primary education and much higher returns for tertiary.

These secondary and post-secondary returns appear to be high but the numbers need to be interpreted with some care. Table 2 Column [1] implies that if the average years of secondary schooling in the African population doubled from 0.6, its average over the period since 1960, to 1.2 then GDP per 
capita would rise by 12 per cent. Similarly if the average years of tertiary education doubled from 0.03 to 0.06 GDP per capita would increase by the same amount. The implication is that even with these OLS estimates, which appear highly significant and large, very large changes in the population with seondary and post-secondary education have very modest effects on GDP per capita.

The data from Barro and Lee show that in 1950 among the advanced countries, mainly OECD members, the average level of education was little above primary school. Further the advances in education post-date the accelerations in growth rates shown so clearly in Figure 1, a point emphasised by Pritchett $(2001,2009)$. Such correlations suggest that education may be caused by growth rather than causing it, a possibility investigated by Bils and Klenow (2000) who argue on the basis of their macro data that causality does run from growth to education rather than the normal assumption which underlies the growth accounting literature that education causes growth. It seems very clear that causality may go both ways and in the African context we need to recognise that education and growth may be related in both directions. If that is so then the above effects which we have already noted are moderate, may well be overstatements of any causal effects of education onto GDP.

Table 2 has presented education effects in the context of a formal production function. In investigating how closely investments in education are related to changes in income the approach adopted by Pritchett $(2001,2009)$ is a graphical one. We show in Figure 3 how incomes and education are related for Africa. The left hand chart in Figure 3 shows for the average of 2000-2004 the correlation between the Barro and Lee measure of human capital - the average years of education of the population aged over 15 - and the measure of world incomes from the PENN (6.3) World Tables, (see Heston, Summers and Aten (2009)). The right hand chart shows a similar plot of the changes in income and the changes in education over the period from 1960 to 2000 again based on the same five year averages that underlie Table 2. While the correlation between GDP and education appears quite close when we look at levels it is much less so when we look at growth rates.

Figure 3 Incomes and Education in sub-Saharan Africa

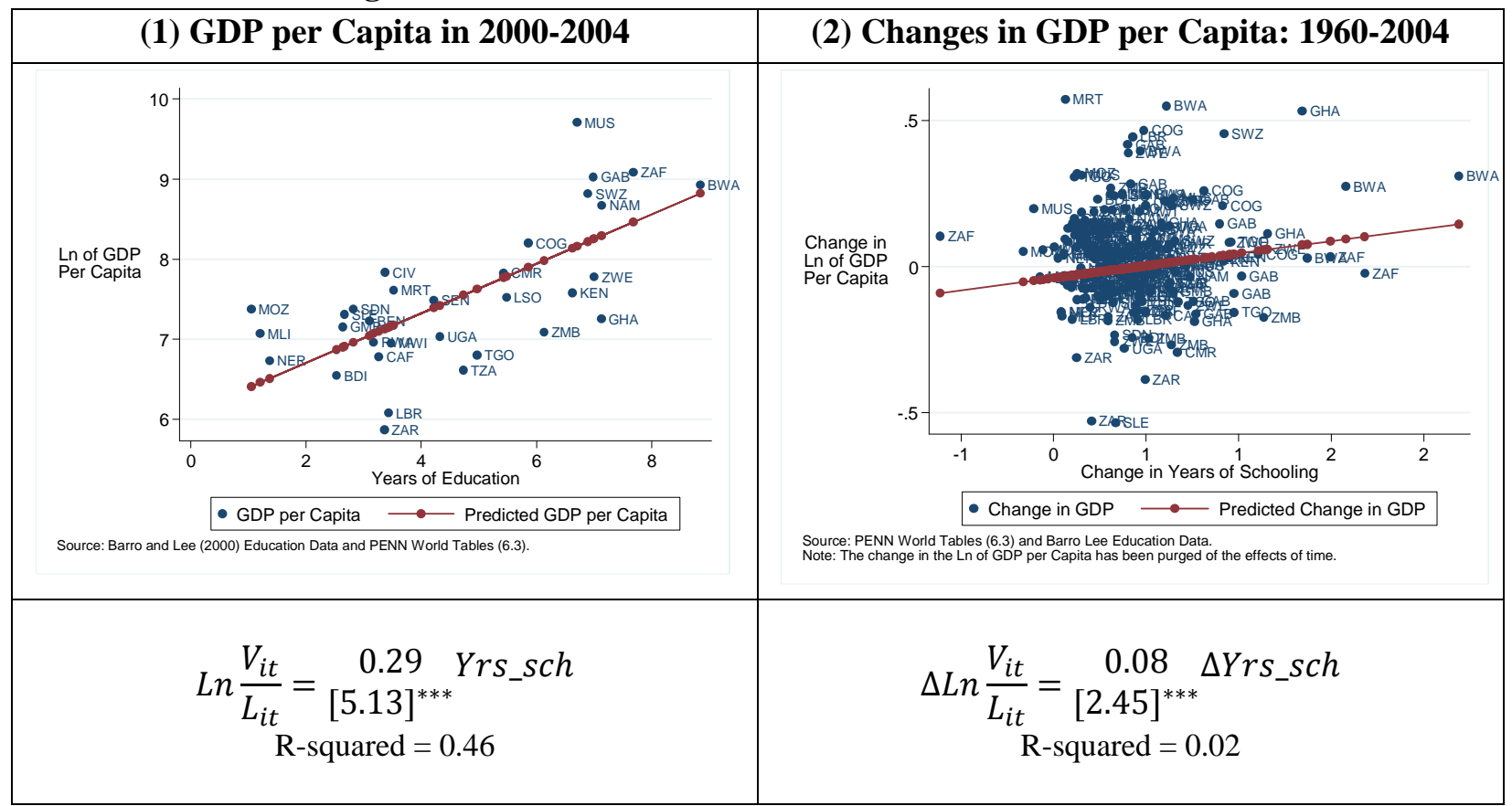

The figures in [ ] parentheses are $t$ statistics ** significant at 5\%; *** significant at 1\% 
This last point is the one emphasised by Pritchett (2009). He argues that if we want to understand changes in income then there is little, if any, correlation between those changes and changes in the level of education. Indeed for the world data which underlie Prichett's analysis there is a slight negative relationship. Again this result needs to be treated with caution. Firstly the pattern for Africa appears different from other countries with education having a stronger impact than for non-African countries for the production function estimated in Table 2. Secondly while there is only a rather weak correlation between changes in education and changes in income the point estimate on the relationship shown in chart 2 of Figure 3 of 0.08 is identical to that shown in the regression of Table 2 implying that this effect appears not to work through physical capital .

In Figure 4 we present a similar chart for the relationship between GDP and the physical capital stock. Again we see that the relationship in changes is weaker than the relationship in levels but, and this point is critical, the relationship in changes is much closer than that for education. It will be noted that even in differences the point estimate on the capital stock is 0.5 , which is far above the 0.3 assumed in the calibration exercises. As for Figure 3 the data is confined to sub-Saharan African countries although a very similar pattern emerges for the data for all countries.

Figure 4 Incomes and Physical Capital in sub-Saharan Africa

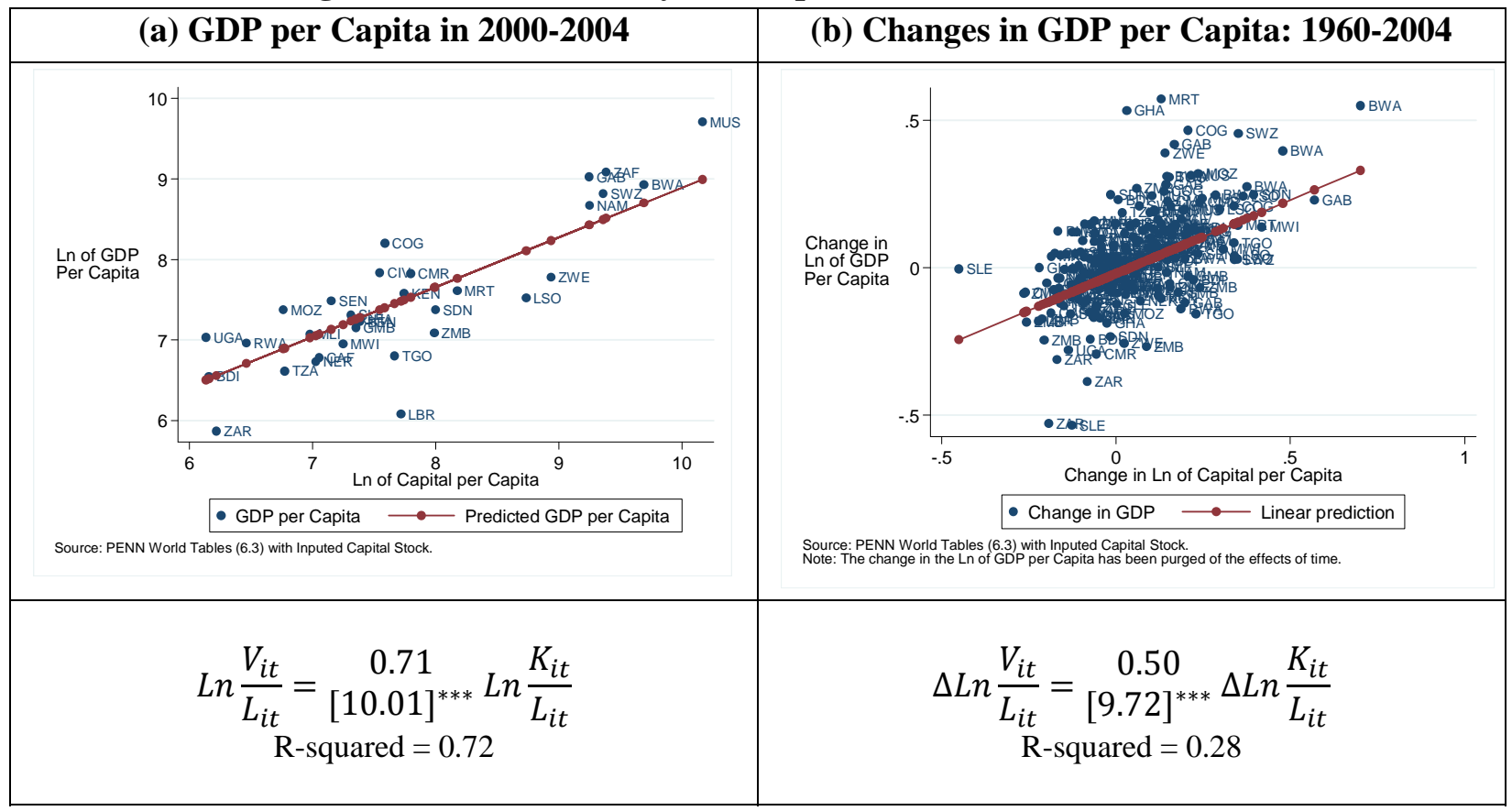

Figures 3 and 4 present the limits of how either physical or human capital can explain the changes in output we have seen over the period from 1960 to 2004. They need to be compared with the results reported in Table 2 where we do not impose constant returns to scale and we allow both physical and human capital to determine GDP. It is clear from Table 2 that physical capital dominates human capital as a determinant of output. However this result depends on a value for the parameter on capital which is known to be inconsistent with the share of capital in GDP from the national accounts. That result is also found for all countries and remains an anomaly which must give rise to reservations as to whether the effects of human capital have been modelled correctly.

The graphical analysis has focused on the role of years of education in determining GDP. We stress again this is the average, it is clear from the results in Table 2 that for Africa these effects are higher 
at higher levels of education in the macro data and this result is robust across all the estimators we report in that Table. What is not robust across the estimators is the role of tertiary education. While the effects of tertiary education are large and highly significant in the OLS this is not the case for either the fixed effect or first difference estimator. This may reflect the inability to capture the effect but more likely it is that it does reflect bias from some time-invariant common factor.

These results present us with a puzzle. How can physical capital be so dominant in the macro data? It seems clearly absurd to think that if all Tanzania did was to change its physical capital stock so it looked like the US it would have the US level of income. One possible answer is that we cannot change the physical capital stock without changing the level of education and that we must look elsewhere for an understanding of how productivity links to education. In the next section we pose this question of the micro data.

\section{Human capital and incomes: the micro empirical evidence}

How can we reconcile these very high growth rates of education with the very low growth of incomes within Africa? Further, how can they be reconciled with the results of micro studies which report very high returns on education? And how is what we observe related to the patterns of growth within education? We will argue that the answer to all these questions is related to the underlying shape of the earnings function. Understanding that is the key to understanding the results we observe for the average level of education. Further the shape of the earnings function has implications for the possible reasons as to why the demand for higher education has been expanding so rapidly in economies with low growth rates.

The earnings function is probably the most studied relationship in empirical economics. Its origins lie in seminal studies by Becker (1962) and Mincer (1974) investigating how individual earnings are related to investments in human capital specifically education and experience in the labour market. In a recent review of the history of the Mincerian earnings function Heckman, Lochner and Todd (2009) argue that the US census data does not support the linearity assumption between the log of earnings and education which underlies the Mincerian model. The implications of non-linearity in the earnings education function are wide ranging. If this relationship is non-linear then the value of education in the early part of the education cycle is in part the value of being able to continue to the next stage. Heckman, Lochner and Todd (2009) term this the "option value” of education.

What does determine the shape of the earnings function and can we identify it? To see the nature of the problem and why the shape of the function is so critical for any discussion of investment in higher education re-consider the most basic earnings function which we have already introduced in the context of macro production functions:

$$
L n w_{L_{(i t)}}=\delta_{0}+\delta_{1} E_{i}+\delta_{2} E_{i}^{2}+v_{i t}
$$

In the context of the micro earnings function this specification would be extended to include work experience and, in the original Mincerian specification, linearity. An extension of this function would be of the following form:

$$
\operatorname{Ln}\left(w_{i t}\right)=\varphi_{1}\left(E_{i}\right)+\varphi_{2} \text { Exper }_{i t}+\varphi_{3} \text { Exper }_{i t}^{2}+\alpha_{i}^{w}+v_{i t}
$$


$\varphi_{1}($.$) is the function capturing the effect of schooling on wages. The return to experience (denoted$ Exper $_{i t}$ ) is captured in $\varphi_{2}$ and $\varphi_{3}$ while $\alpha_{i}^{w}$ is unobserved labour market ability. This is the form of the function used by Belzil and Hansen (2002). At the micro level the central concern has been the potential endogeneity of education in such a specification which would arise if market ability was correlated with education. The Belzil and Hansen (2002) formulation is unusual in two respects. The first is that they are agnostic as to the shape of the earnings function. The second is that they explicitly model the possible correlation between aptitude for schooling and market ability in the context where different types of individuals can be identified.

An extension of the notion that there is an individually specific aspect of the return to education adopts a linear specification but one in which the return to education is individually specific as in:

$$
\operatorname{Lnw}_{L(i t)}=\alpha_{\mathrm{i}}^{\mathrm{W}}+\beta_{i} E_{i}+\varphi_{2} \operatorname{Exper}_{i t}+\varphi_{3} \operatorname{Exper}_{i t}^{2}+v_{i t}
$$

This specification allows for heterogeneity both in the level of earnings $\alpha_{i}^{w}$ and in the returns to earnings $\beta_{i}$. The equation can be rewritten in the following form so that it is clear that the parameter on $E_{i t}$ is an average treatment effect, $\bar{\beta}$ :

$$
\operatorname{Lnw}_{L_{(i t)}}=\alpha_{\mathrm{i}}^{\mathrm{w}}+\bar{\beta} E_{i}+\left(\beta_{i}-\bar{\beta}\right) E_{i}+\varphi_{2} \operatorname{Exper}_{i t}+\varphi_{3} \operatorname{Exper}_{i t}^{2}+v_{i t}
$$

It is an equation of this form that is the focus for the Card (2001) analysis as to the potential sources of bias in the OLS estimate of the earnings function. Specifically the Card paper seeks to assess whether an instrumental variable approach can successfully address the endogeneity problems posed by this equation. An important result is that attempts to allow for the potential correlation between ability and schooling have led to estimates of the return to education which are higher than those in OLS. What might account for such a finding? One possibility, assessed by Card (2001), is that the experiments which underlie the attempt to allow for the endogeneity of education are focusing on a lower part of the educational distribution where the returns are concave.

A second explanation, which is reviewed by Heckman, Lochner and Todd (2009), is in terms of comparative advantage. Interpreting the results of an earnings function as causal implies that the earnings of those with say 15 years of education can be compared with those with 10 such that the difference is the earnings increment for those with the additional five years of education. However what if those with 15 years of education would have had lower earnings than those with 10 years if they had themselves only had 10 years of education. In that case the OLS results are an underestimate of the return for those who do go on to get 15 years of education. Essentially this is an argument that comparative advantage will play an important role in determining the actual returns to education.

What does the earnings function look like if we estimate the function by OLS with controls for market experience? Figure 5 shows the results of an earnings function which pools data across 22 countries and several time periods. The data is from Trostel, Walker and Woolley (2002) where the data across countries has been made comparable by converting the local currency into purchasing power parity US\$.

\footnotetext{
${ }^{1}$ There are 26 countries in the Trostel, Walker and Woolley (2002) data set of which 22 are used in Figure 5, they are Australia, Austria, Bulgaria, Canada, Switzerland, Spain, Hungary, Ireland, Israel, Italy, Japan, Latvia,
} 
Figure 5

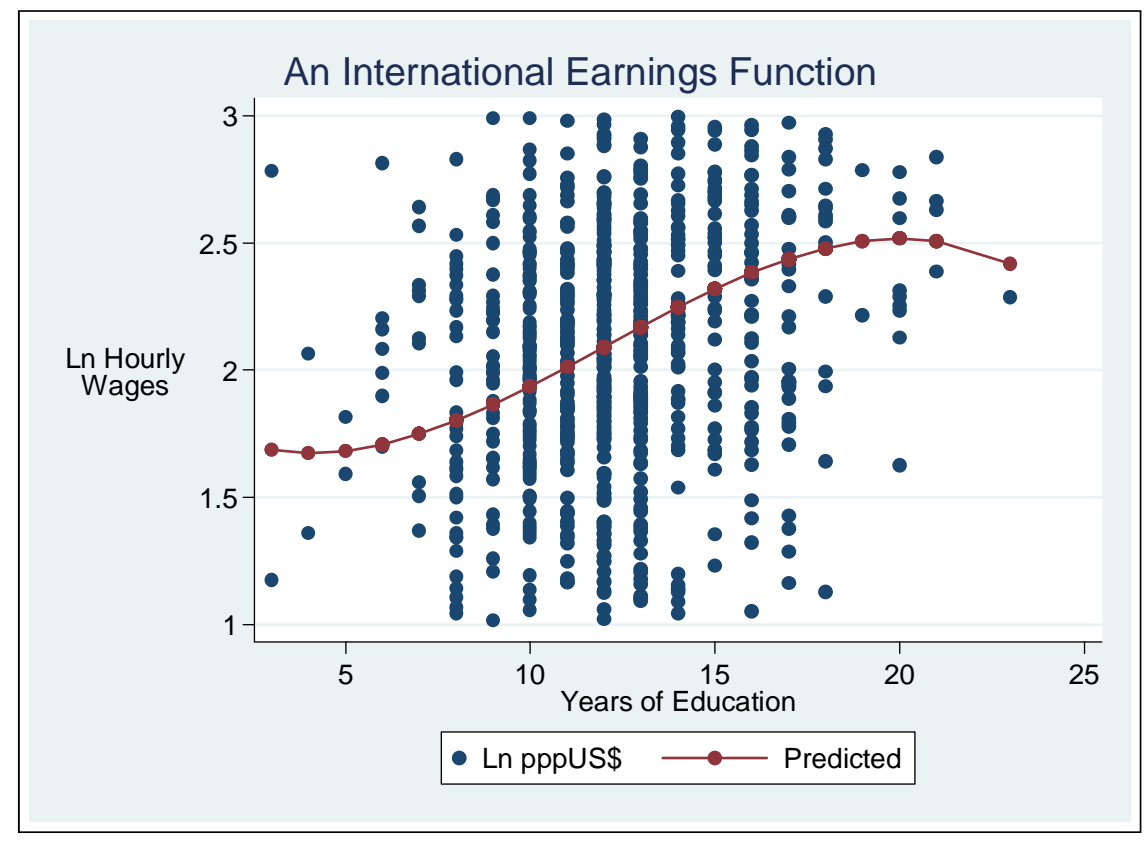

Two features of the data are striking. The first is that the earnings function is clearly non-linear, the second is that education explains a relatively small share of the income across the individuals in the data. The shape of this function appears to be convex up to about 15 years of education and concave after that point. It is of course at exactly that point that tertiary education begins. The finding that education explains a relatively small share of the distribution of earnings has led some to argue that the theory is grossly incomplete as an explanation of earnings. Mortensen (2003, p. 1) writes: "Although hundreds if not thousands of empirical studies that estimate so-called human capital wage equations verify that worker characteristics that one could view as indicators of labor productivity are positively related to wages earned, the theory is woefully incomplete in its explanatory power. Observable worker characteristics that are supposed to account for productivity differences typically explain no more than 30 per cent of the variation in compensation across workers in these studies”.

The data underlying Figure 5 provides a context for this argument of Mortensen. The person on the earnings function with fifteen years of education will earn more than twice the one with five year of education, which converts into a Minerian rate of return of about 8 per cent per annum. We can either be impressed at the value of education - it doubles earnings - or distressed that there is so much variation of earnings for those with identical levels of education which is true both within and across countries.

The other important feature of the earnings function shown in Figure 5 is that over much of its range it is clearly convex. Such convexity contrasts with the argument of Psacharopoulos that the return to education is concave (Psacharopoulos, 1994; Psacharopoulos and Patrinos, 2001). ${ }^{2}$ If in fact the earnings function is convex, so that the marginal returns to education are lowest for the individuals

Netherlands, Norway, New Zealand, Philippines, Poland, Slovak Republic, Slovenia, Sweden, and the US. While there is no panel element to the data there are repeated cross sections for most of the countries.

${ }^{2}$ In a series of papers Bennell (1996a,b; 2002) has argued that the pattern of the returns to education do not follow that asserted by Psacharopoulos (1994). Bennell's underlying arguments are consistent with the shape being convex. Direct evidence of convexity in some parts of the domain of the earnings function is provided by Belzil and Hansen (2002) for the U.S. and by Kingdon and Unni (2001) and Duraisamy (2002) for India. 
with the least education, giving priority to investment in primary education may have little impact on incomes unless the individuals affected by the reforms proceed to higher levels of education. Further the convexity of the earnings function will provide a powerful incentive to pursue higher education even though the returns to lower levels of education are modest. It is for this reason that the shape of the earnings function facing those investing in education is so crucial.

If the shape of the earnings function is as shown in Figure 5 for Africa (the data on which it is based does not contain African countries) then we have at the individual level the answer to the question posed in the introduction as to how higher education impacts on earnings. But what is the evidence for Africa? In Figure 6 we have collated the data for wage employees taken from a series of manufacturing firm level surveys in Africa over the period from the early 1990s to 2003.

Figure 6: Earnings in Manufacturing Firms in Africa

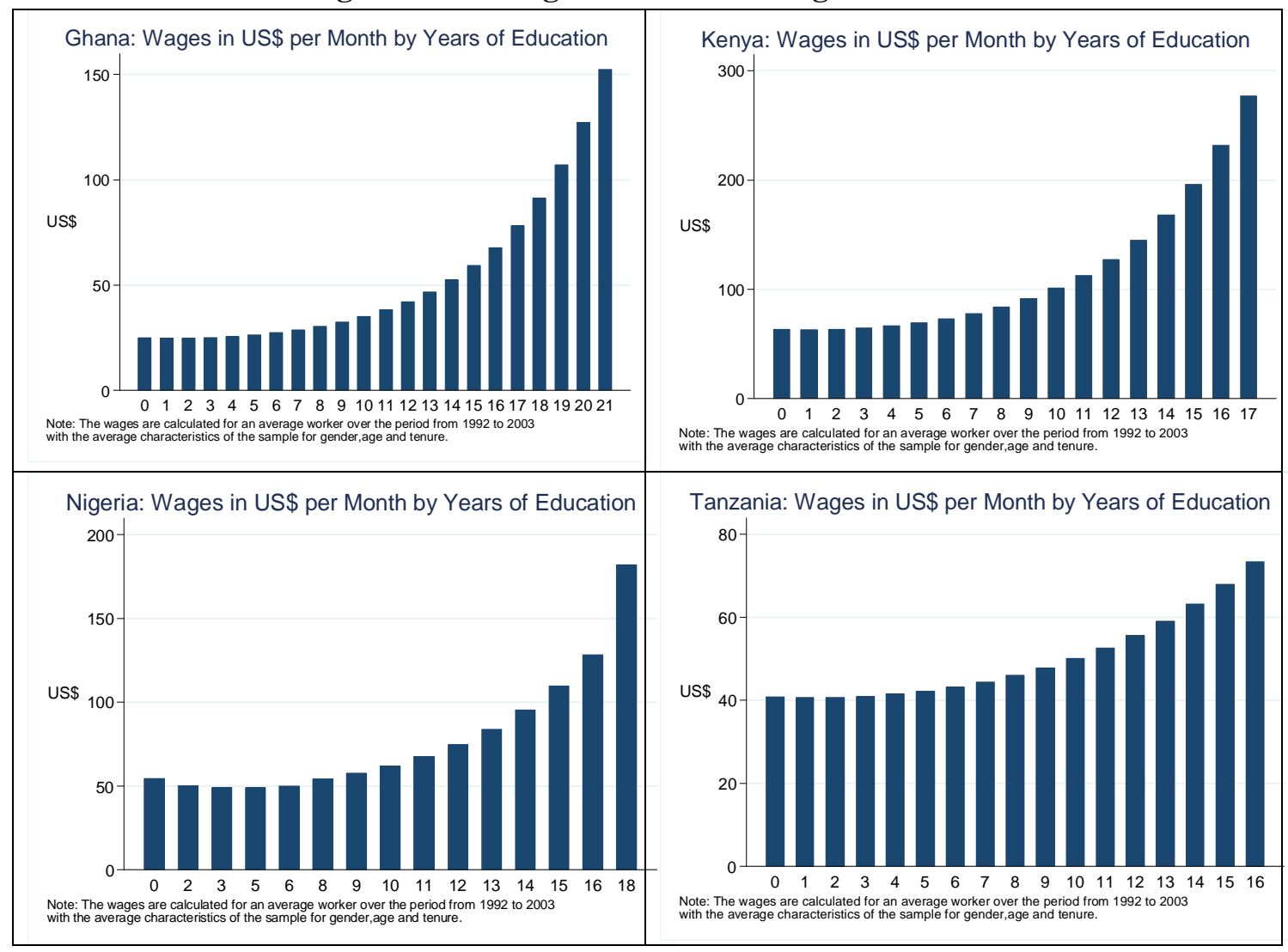

Source: The data for Ghana and Kenya are from the sources given in Bigsten et al (2000). The Tanzanian data is from Kahyarara (2005). The Nigerian data are those used in Malik and Teal (2008).

These are all economies in which both manufacturing and wage employment are a small part of the economy. Thus issues of selection are likely to be of particular importance. In Söderbom, Teal, Wambugu and Kahyarara (2006) these issues of endogeneity are investigated for the Kenyan and Tanzanian data. They can find no evidence that the clear pattern of convexity apparent in the data is due to a selection process by which the relatively able enter at higher levels. What is also striking is that the pattern is even more strongly convex that that shown in Figure 5 which is confined to nonAfrican countries. It is clearly highest for those with tertiary education. 
In seeking to compare the returns to higher education in Africa with those shown in Figure 5 we face other problems. The first is that many tertiary educated people work in the public sector and we need data that allows us to distinguish between public and private employment. The second is that the employment outcomes amongst the educated have been changing as the structure of employment within African economies has been changing. As we will discuss below one of the most important employment trends in Africa is the rise in informal employment in the form of self-employment and the small scale firm sector, Kingdom, Sandefur and Teal (2006). It is quite possible that the returns to education will differ by these sectors of employment and we need appropriate data in order to be able to address that question.

We need to be able to compare those in wage and non-wage employment. There is much less comparative work on which we can draw. However some recent work at the CSAE has sought to provide direct comparisons of the returns to wage and self-employment in Ghana and Tanzania. Rankin, Sandefur and Teal (2010) investigate labour market outcomes of urban workers in Ghana and Tanzania. They find that the returns to education are far higher in the large firm sector than in others and in this sector they are linear not convex. In both countries there is clear evidence of convexity in the returns to education for the self-employed and here the average returns are low. It is possible that the pattern of convexity which is so pronounced in Figure 6 hides important differences across firms of differing size. However, as they stand, both the firm level data and that for self-employment from labour force surveys points to a pattern of convexity in the returns to education very similar to the international pattern reported in Figure 5.

\section{Jobs and Higher Education: Where do the tertiary educated work and why?}

The last section focused on how the returns to education differ by its level. That discussion was exclusively concerned with the productivity effects of investing in education. As was noted in the introduction that is not the only role played by investment in education. The jobs individuals have are closely linked to their levels of education and the returns to education operate in part through access to particular types of jobs.

We noted above that one empirical finding which surprised researchers was that once one sought to allow for the possible bias in the OLS the instrumental variable results suggested these estimates were downward biased. A second empirical "surprise" in the measurement of the return to education was that, at least in the US, the return to education rose when the levels of education rose. A finding clearly at variance with any simple model of the demand and supply of skills by which increasing skills would reduce their price. The key facts were set out in a paper by Acemoglu (1999) which also sought to explain them:

"Between 1979 and 1987, the average weekly wages of college graduates with one to five years of experience increased by 30 percent relative to the average weekly earnings of comparable high-school graduates [sources given in the paper] .. after controlling for education and experience, the differential between the ninetieth and the tenth percentile wages stood at 118 percent in 1988 compared to 92 percent in 1970 .. the rise in inequality over this period was not only due to wage increase for highly paid workers. Real wages of high-school graduates with one to five years of experience, for example, fell by 20 percent from 1979 to 1987. Meanwhile the unemployment rates of all education groups have increased. In 1970 the unemployment rate for civilian males between the ages of 25 and 64 with less than four years of high school was 4 per cent. For those with high-school and college degrees, the 
same numbers were 2.4 per cent and 1.1 percent. Averaged between 1992 and 1994 the unemployment rates for these three groups were respectively 13.9 percent, 6 percent and 3.2 percent, approximately three times higher than the rates during the 1970s.” Acemoglu (1999)

So how can these key facts be explained? Acemoglu builds a model which suggests that when the supply of skills increases the incentives of firms to create more skilled jobs also increase. Why? The intuition of the model is that if both the productivity differential between skilled and unskilled workers and the share of the workforce that is skilled is sufficiently low then firms will not have an incentive to create high quality jobs. However as both dimensions of skills increase firms may find in more profitable to create higher quality jobs and the economy will flip to a new equilibrium with two classes of firm. In other words in moving between equilibria the wages of skilled workers will rise, those of unskilled workers will fall and unemployment will increase. ${ }^{3}$

This model is of relevance to any attempt to understand what expanding the supply of skilled labour may do. The growth in the tertiary educated, which as we showed in section 2 has occurred in Africa as fast as it has occurred elsewhere, has in other countries been associated with a rise in their price and the expansion of jobs for the relatively skilled. How have jobs in Africa changed over the relatively recent past?

Figure 7 which is taken from Kingdon, Sandefur and Teal (2006) provides a comparative answer to that question over the decade of the 1990s. The pattern is clear that where jobs, as distinct from open unemployment, have been expanding it has been in the self-employed sector. More recent data from Ghana shows in the period since 1999 a rapid expansion of wage employment in small firms, Nsowah-Nuamah, Teal and Awoonor-Williams (2010). So what we observe is a fall in public sector employment and a rise in employment in small scale enterprises.

In order to link the outcomes shown in Figure 7 to higher education we need to know how the probability of changing occupation relates to the level of education. In Table 3 the data is drawn from a study of urban outcomes in Ghana and Tanzania for 2004 and 2005, Rankin, Sandefur and Teal (2010). It shows in Ghana and to a greater extent in Tanzania a pattern by which the probability of being employed in the public sector rises with education and is highest for those with university education. That fact is not a surprise. What is more striking is that after employment in the public sector it is self-employment that is by far the most common outcome, not employment in private firms.

\footnotetext{
3 “A more novel explanation for the U.S. labor market trends also emerges from this simple model. The supply of skilled workers in the U.S. labor market increased sharply during the 1970's. A simple relative supplydemand approach would predict a decline in the relative wages in response to this increase. In the data, however, the large increase in the supply of skills during the 1970's is followed by a rise in the skill premium. In my model, when skilled workers become more abundant, firms find it profitable to design jobs for them rather than pool across the two skill groups. This transforms the structure of the labour market, increasing returns to education, residual inequality and unemployment. Therefore in contrast to the conventional approach, my theory predicts that even if technological possibilities remain unchanged, an increase in the proportion of skilled workers can switch the economy from a pooling to a separating equilibrium and increase inequality.” (page 1265)
} 


\section{Figure 7 Trends in Non-Agricultural Employment by Sector}

(Absolute No. of Workers in Thousands)

The right hand axis refers to Ethiopia and South Africa and the left hand axis to the other countries

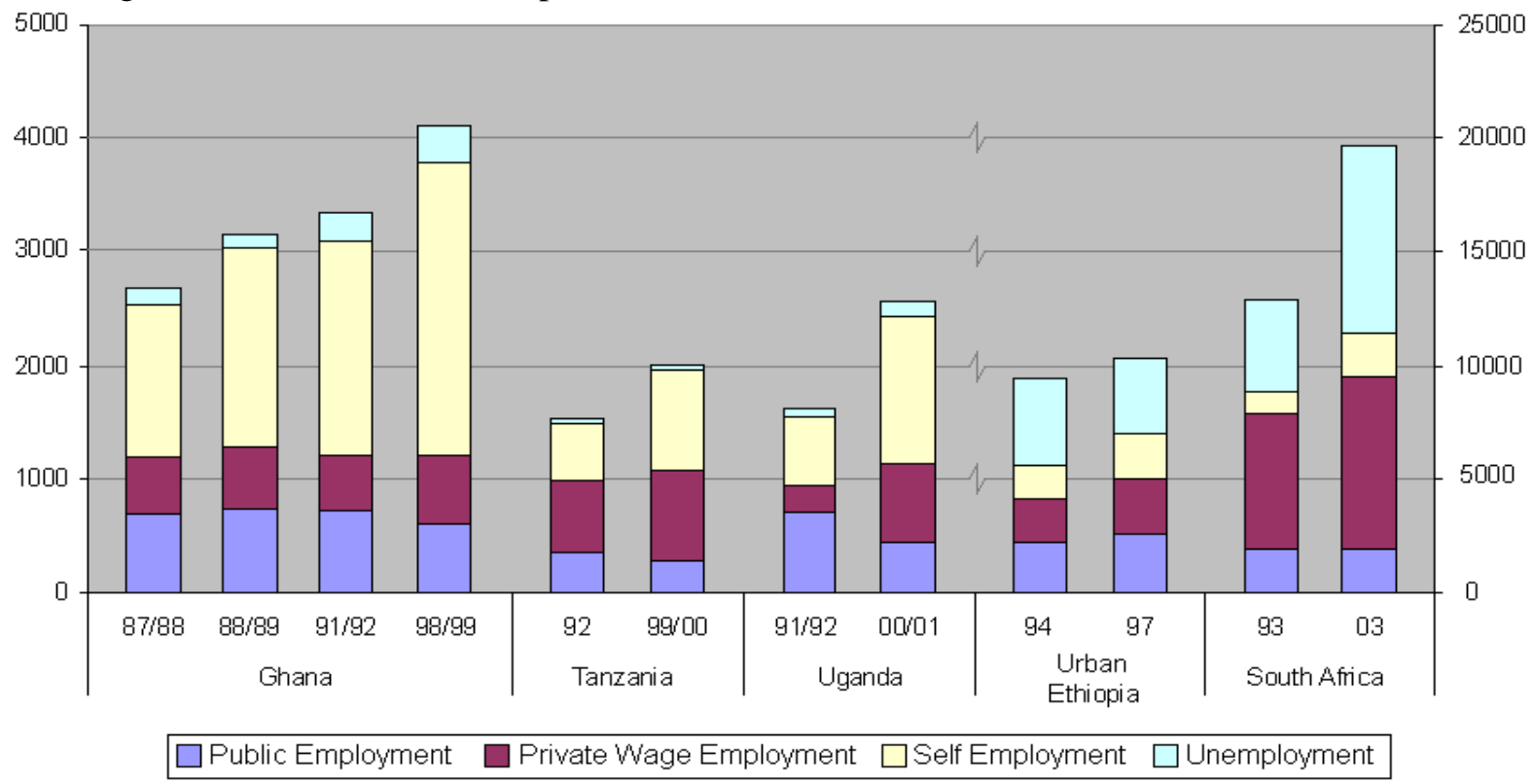

So how do earnings compare across these occupations? Again drawing on the same data this is shown in Table 4. We see there, as we would expect from the data in Table 3, that those in public employment have very substantially higher levels of education than those in the private sector. In Ghana, but not in Tanzania, education levels are higher in larger firms. In the case of self-employment and work in small firms the levels of education are similar at 9 years in Ghana, essentially the end of junior secondary school and at 7 in Tanzania, essentially the end of primary school. The earnings gap between those in small scale employment and those in public sector is substantial, over twice in both Ghana and Tanzania.

Table 3 Probabilities of Being in Occupations as a Function of Education

Ghana

$\begin{array}{ccccc}\begin{array}{c}\text { Self- } \\ \text { employment }\end{array} & \text { Small Firm } & \text { Large Firm } & \text { Public Sector } & \begin{array}{c}\text { No } \\ \text { employment }\end{array}\end{array}$

\begin{tabular}{lccccc}
\hline None & 0.62 & 0.09 & 0.01 & 0.00 & 0.27 \\
$\begin{array}{l}\text { Junior } \\
\text { Secondary }\end{array}$ & 0.52 & 0.09 & 0.05 & 0.02 & 0.32 \\
$\begin{array}{l}\text { Senior } \\
\text { Secondary }\end{array}$ & 0.42 & 0.08 & 0.08 & 0.06 & 0.36 \\
& & & & & \\
\hline
\end{tabular}




\begin{tabular}{llllll}
\hline University & 0.29 & 0.06 & 0.11 & 0.17 & 0.37 \\
\hline
\end{tabular}

\section{Tanzania}

\begin{tabular}{lccccc}
\hline None & 0.79 & 0.05 & 0.05 & 0.01 & 0.10 \\
$\begin{array}{l}\text { Junior } \\
\text { Secondary }\end{array}$ & 0.72 & 0.07 & 0.05 & 0.10 & 0.05 \\
$\begin{array}{l}\text { Senior } \\
\text { Secondary }\end{array}$ & 0.62 & 0.06 & 0.05 & 0.24 & 0.04 \\
University & 0.41 & 0.03 & 0.03 & 0.50 & 0.03 \\
\hline
\end{tabular}

Source: Rankin, Sandefur and Teal (2010).

Table 4 Earnings and Education in Urban Ghana and Tanzania: 2004-2005

\begin{tabular}{|c|c|c|c|c|c|c|}
\hline & \multicolumn{3}{|c|}{ Ghana } & \multicolumn{3}{|c|}{ Tanzania } \\
\hline & $\begin{array}{l}\text { Ln (Monthly } \\
\text { Earnings in } \\
1995 \text { prices) }\end{array}$ & $\begin{array}{l}\text { Monthly } \\
\text { Earnings in } \\
\text { US\$ }\end{array}$ & $\begin{array}{l}\text { Education in } \\
\text { Years }\end{array}$ & $\begin{array}{l}\text { Ln (Monthly } \\
\text { Earnings in } \\
1995 \text { prices) }\end{array}$ & $\begin{array}{l}\text { Monthly } \\
\text { Earnings in } \\
\text { US\$ }\end{array}$ & $\begin{array}{c}\text { Education in } \\
\text { Years }\end{array}$ \\
\hline & Mean & Median & Median & Mean & Median & Median \\
\hline Self & 10.92 & 45 & 9 & 5.43 & 39 & 7 \\
\hline Employment & & (754) & & & (618) & \\
\hline Small & 10.67 & 34 & 9 & 5.12 & 33 & 7 \\
\hline Firm & & (157) & & & (72) & \\
\hline Large & 11.47 & 72 & 11 & 5.80 & 57 & 7 \\
\hline Firm & & (123) & & & (69) & \\
\hline Public & 11.77 & $\begin{array}{c}98 \\
(97)\end{array}$ & 14 & 6.20 & $\begin{array}{c}98 \\
(151)\end{array}$ & 12 \\
\hline $\begin{array}{l}\text { Not } \\
\text { Employed }\end{array}$ & NA & NA & $\begin{array}{c}10 \\
(509)\end{array}$ & NA & NA & $\begin{array}{c}7 \\
(61)\end{array}$ \\
\hline Total & $\begin{array}{r}11.02 \\
(1131) \\
\end{array}$ & $\begin{array}{c}45 \\
(1131) \\
\end{array}$ & $\begin{array}{c}10 \\
(1640)\end{array}$ & $\begin{array}{c}5.57 \\
(910)\end{array}$ & $\begin{array}{c}47 \\
(910) \\
\end{array}$ & $\begin{array}{c}7 \\
(971)\end{array}$ \\
\hline
\end{tabular}

Figures in ( ) are the number of observations.

Source: Rankin, Sandefur and Teal (2010).

These results show the dilemma facing the newly educated in these countries. The higher paying jobs are contracting relative to the low paying ones and those with higher levels of education are finding it 
increasingly difficult to find work either in the public sector or large firms. It is possible, we do not know, that these changes are affecting the return to higher education.

\section{Must countries climb similar mountains or can they play leap frog?}

What we have seen in Africa in the period since the mid 1990s is a rapid recovery from the falls in income of the previous decades. While this recovery is clearly a dramatic improvement in the performance of economies within Africa it has occurred at a time when other countries, particularly China and India, have seen spectacular rises in their underlying growth rates. We began this essay by putting those accelerations into an historical perspective. Their common characteristics are that they were very recent and very rapid. In understanding the potential for economic development in Africa we need to understand how Africa can grow equally rapidly and, for the purposes of this essay, the role of education generally and higher education in particular in that process.

One interpretation of the experience of India and China is that they have benefited from being so behind. In China the productivity gains from shifting from rural to urban based activities may have been substantial. In India the liberalisation of the 1980s combined with the revolution in technology made possible rapid growth of the service sector. The rapid advances of mobile phone technology in Africa have raised the prospect that Africa too could see a service based revolution. The patterns of growth differ greatly between India and China and these differences imply very different patterns for the demand for the relatively skilled labour produced by the higher education sector.

Broadly speaking a service based IT sector requires much more skilled labour than a manufacturing based export sector. In India the IT sector has been a major employer of graduates. As we have seen where we have data in Africa the service based self-employed sector is becoming an important employment outcome for the higher educated.

This rise of self-employment in Africa is open to at least two very different interpretations related to the title of this section - must countries climb similar mountains or can they play leap frog? One view would be that there is a given pattern of economic development by which poor labour intensive countries need to begin with exports of goods which are labour intensive. China would be seen as a classic example of such a successful growth strategy. This is the view that countries need to climb similar mountains and that as they grow output will shift to higher skill activities as wages rise. Another view is that the revolution in information technology has opened up potentially different paths, ones using skilled labour much earlier in the growth process and one where demand for skilled labour may rise even in very poor economies. India it could be argued is an exemplar of such possibilities. These very different paradigms imply very different views of how higher education will link to the development process.

Can Africa use its investment in higher skilled labour to affect such a service based growth revolution? The appearance of clusters of skilled labour in parts of some African countries has 
suggested such a possibility. ${ }^{4}$ Two aspects of this possible transformation need to be noted. The first is that any such process involves a shift away from public sector employment as being the most important source of employment for the higher educated. The second is that a common factor across both the Chinese and Indian experience is that the high growth sectors were able to produce goods which were competitive at international prices. While Africa is producing jobs in self-employment for the higher educated this link to exporting is largely missing. While it remains so the alternative picture of self-employment as an employer of last resort for those whose education no longer gets them the wage job they seek may be the reality facing many job seekers in Africa.

What both our micro and macro data has shown is that the return to education appears to rise with its level. The evidence is not clear cut that it is highest at the tertiary level but that certainly seems to be the case for wage employment within Africa. If this is so, and the underlying earnings function facing those investing in education is convex, then there is a substantial "option" value to education which can explain how a massive excess demand for such education can co-exist with very modest effects at the macro level of the investment in education on the level of incomes in African countries.

That finding highlights the policy dilemma facing those deciding on investments in education. As post secondary education is only available to those with lower levels, investing in primary and secondary is a pre-condition to being able to expand education at the tertiary level. At present we have very little, if any, evidence that the expansion at primary education that has occurred has resulted in increased incomes. Will expanding beyond that level be more effective? The evidence we have presented in this paper suggests that the answer to that question may depend on how educational expansion is linked to other forms of investment and those linkages remain very poorly understood.

\footnotetext{
${ }^{4}$ Oyelaran-Oyeyinka (2007) provides an interesting account of the development of a computer hardware cluster in Otigba Nigeria which illustrates the possible link between highly skilled labour and self-employment. Mousley (2010) discusses this issue more generally in the context of Nigeria.
} 


\section{References}

Acemoglu, D. (1999) "Changes in unemployment and wage inequality: an alternative theory and some evidence.” American Economic Review, 89(5) (December), pp. 1259-1278.

Barro, R.J., Lee, J-W. (1993) "International comparisons of educational attainment”, Journal of Monetary Economics, 32, 363-394.

Barro, R.J., Lee, J-W. (2000) International data on educational attainment: Updates and implications. CID Working Paper no. 42.

Barro, R.J., Lee, J-W. (2010) A new data set of educational attainment in the world, 1950-2010, NBER Working Paper 15902.

Becker, G.S. (1962) "Investment in Human Capital: A Theoretical Analysis.”Journal of Political Economy 70, suppl. (October 1962): 9-49.

Belzil, C. and Hansen, J. (2002) "Unobserved ability and the return to schooling." Econometrica, 70(5) September, pp. 2075-2091.

Benhabiib, J., Speigel, M. (1994) "The role of human capital in economic development: Evidence from aggregate cross-country data”, Journal of Monetary Economics 34, 143-173.

Bennell, P. (1996a) "Rates of return to education: does the conventional pattern prevail in SubSaharan Africa?” World Development, Vol. 24, pp.183-199.

Bennell, P. (1996b) "Using and abusing rate of return: a critique of the World Bank's 1995 Education Sector Review”, International Journal of Educational Development, Vol. 16, pp. 235-248.

Bennell, P. (2002) "Hitting the target: doubling primary school enrollments in Sub-Saharan Africa by 2015”, World Development, Vol. 30, pp.1179-1194.

Bigsten, Arne, Paul Collier, Stefan Dercon, Marcel Fafchamps, Bernard Gauthier, Jan Willem Gunning, Anders Isaksson, Abena Oduro, Remco Oostendorp, Cathy Pattillo, Måns Söderbom, Albert Zeufack, and Simon Appleton (2000) "Rates of return on physical and human capital in Africa's manufacturing sector." Economic Development and Cultural Change, Vol. 48 (4) pp. 801-827.

Bils, M. and Klenow, P. (2000) “Does schooling cause growth?” American Economic Review, 90(5) December, pp. 1160-1183.

Card, D. (2001) "Estimating the return to schooling: progress on some persistent econometric problems." Econometrica, 69(5) September, pp. 1127-1160.

De Meulemeester, J. and Rochart, D. (1995) "A causality analysis of the link between higher education and economic development." Economics of Education Review, 14(4), 351-361.

Duraisamy, P. (2002) "Changes in returns to education in India, 1983-94: by gender, age-cohort and location,” Economics of Education Review, Vol. 21, pp. 609-622.

Caselli, F. and Coleman, W. (2006) "The World Technology Frontier" American Economic Review June.

Gyimah-Brempong, K., Paddison, O., and Mitiku, W. (2006). "Higher education and economic growth in Africa.” Journal of Development Studies, 42(3), 509-529.

Heckman, J.J., L.J. Lochner and P.E. Todd (2009) "Earnings functions, rates of return, and treatment effects: the Mincer Equation and Beyond", Chapter 7 in Handbook of the Economics of Education, Vol. 1 (eds.) E.A. Hanushek and F. Welch, North-Holland, Amsterdam.

Heston, A., R. Summers and B. Aten (2009) Penn World Table Version 6.3, Center for International Comparisons of Production, Income and Prices at the University of Pennsylvania, August.

Kahyarara, G. (2005) Real earnings and productivity in Tanzanian manufacturing firms, DPhil, University of Oxford.

Kingdon, G. G. and Unni, J. (2001). "Education and women’s labour market outcomes in India," Education Economics, Vol. 9, pp. 173-194.

Kingdon, G, Sandefur, J. and F. Teal (2006) Labour market flexibility, wages and incomes in subSaharan Africa in the 1990s”, African Development Review, Vol.18, No.3, December.

Klenow, P.J. and Rodríguez-Clare, A. (1997) The neo-classical revival in growth economics: Has it gone too far? in Bernanke, B., Rotemberg, J., (ed.) NBER Macroeconomics Annual. Cambridge, Massachusetts: MIT Press.

Krueger, A.B., Lundahl, M. (2001) “Education and growth: Why and for whom?” Journal of Economic Literature 39, 1101-1136. 
Maddison, A. (2006) The World Economy (2006) OECD Development Centre. The data is available at: www.ggdc.net/Maddison.

Malik, A. and F. Teal (2008) Towards a more competitive manufacturing sector, Chapter 11 in P. Collier, C. Soludo and C. Pattillo (eds.) Economic Policy Options for a Prosperous Nigeria, Palgrave, Macmillan.

Mankiw, N. G., D. Romer and D. N. Weil (1992) "A Contribution to the Empirics of Economic Growth,” The Quarterly Journal of Economics, Vol. 107, No. 2. May, pp. 407-437.

Mincer, J. (1974) Schooling, Experience and Earnings, New York: National Bureau of Economic Research.

Mortensen, D.T. (2005) Wage Dispersion: Why are similar workers paid differently? The MIT Press.

Mousley, P. (2010) Building the Enterprise Sector for Employment and Growth: Some Policy Options Chapter 4 in V. Treichel (ed.) Putting Nigeria to Work: A Strategy for Employment and Growth, The World Bank, Washington.

Nsowah-Nuamah, N., F. Teal, M. Awoonor-Williams (2010) Jobs, Skills and Incomes in Ghana: How was poverty halved? CSAE Working Paper WPS/2010-01.

Oyelaran-Oyeyinka, B. (2007) Learning in local systems and global links: The Otigba computer hardware cluster in Nigeria, Chapter 6 in B. Oyelaran-Oyeyinka and D. Mccormick (eds.) Industrial clusters and Innovation Systems in Africa, United nations University Press, Tokyo.

Prichett, L. (2001) "Where has all the education gone?” The World Bank Economic Review vol. 15(3), pp. 367-391.

Prichett, L. (2006) Does learning to Add up Add up? The returns to schooling in aggregate data, chapter 11 in Handbook of the Economics of Education, vol. 1 (eds.) E.A. Hanushek and F. Welch, North-Holland, Amsterdam.

Psacharopoulos, G. (1994) "Returns to investment in education: a global update", World Development, Vol. 22, pp. 1325-1343.

Psacharopoulos, G. and Patrinos, H. A. (2002) "Returns to investment in education: a further update”, World Bank Research Working Paper 2881, The World Bank.

Falco, P., A. Kerr, N. Rankin, J. Sandefur, F. Teal (2010) The returns to formality and informality in urban Africa. CSAE Working paper WPS/2010-03

Rankin, N., M. Söderbom and F. Teal (2006) "Exporting from manufacturing firms in sub-Saharan Africa”, Journal of African Economies, Vol. 15, No.4, December, pp.671-687.

Rankin, N., J. Sandefur and F. Teal (2010) Learning \& earning in Africa: Where are the returns to education high? CSAE Working Paper WPS/2010-02

Söderbom, M., F. Teal, A. Wambugu and G. Kahyarara (2006) "The dynamics of returns to education in Kenyan and Tanzanian manufacturing”, Oxford Bulletin of Economics and Statistics, Vol. 68, No.3, pp. 261-288.

Temple, J. (1999) “The new growth evidence”. Journal of Economic Literature 37, 112-156.

Trostel, P., I. Walker, and P. Woolley (2002) "Estimates of the economic return to schooling for 28 countries,” Labour Economics, 9(1), pp.1-16 
Appendix 1: The countries in the sample

\begin{tabular}{ll}
\hline World Bank Code & Country \\
\hline BDI & Burundi \\
BEN & Benin \\
BWA & Botswana \\
CAF & Central African Republic \\
CIV & Cote d'Ivoire \\
CMR & Cameroon \\
COG & Congo, Republic of \\
GAB & Gabon \\
GHA & Ghana \\
GMB & Gambia, The \\
KEN & Kenya \\
LBR & Liberia \\
LSO & Lesotho \\
MLI & Mali \\
MOZ & Mozambique \\
MRT & Mauritania \\
MUS & Mauritius \\
MWI & Malawi \\
NAM & Namibia \\
NER & Niger \\
RWA & Rwanda \\
SDN & Sudan \\
SEN & Senegal \\
SLE & Sierra Leone \\
SWZ & Swaziland \\
TGO & Togo \\
TZA & Tanzania \\
UGA & Uganda \\
ZAF & South Africa \\
ZAR & Congo, Dem. Rep. \\
ZMB & Zambia \\
ZWE & Zimbabwe \\
\hline & \\
\hline & \\
\hline
\end{tabular}




\section{Appendix 2: Constructing a measure of physical capital}

The PWT6.3 data set contains no information on the stock of physical capital. Following Klenow and Rodríguez-Clare (1997) such data are constructed using the capital accumulation equation

$$
K_{i t}=(1-\delta) K_{i, t-1}+I_{i t}, \quad t=1950,1951, \ldots, 2007,
$$

where $I$ is investment in physical capital and $t$ denotes year. This procedure requires data on investment, initial capital $\left(K_{i, 1950}\right)$ and the depreciation rate.

Investment: Investment data is obtained by using the following formula:

$I_{i t}=k i_{i t} \cdot \operatorname{rgdpl}_{i t} \cdot \operatorname{pop}_{i t} \cdot 1,000$,

where rgdpl is the PWT6.3 variable for real GDP per capita (Laspeyres); $k i$ is the investment share of $\mathrm{rgdpl}$; and pop is the population divided by 1,000 .

Initial Capital: For each country we define the initial capital-output ratio as

$\left(\frac{K}{Y}\right)_{1950}=\frac{i}{g+\delta+n}$

where $i, g$ and $n$ are country averages of the investment to output ratio $(k i)$, the growth rate of per capita income (based on the PWT6.3 variable rgdpl) and the population growth rate (based on pop), respectively, for all observations available in the 1950-1965 period. The depreciation rate is set as explained in the next paragraph. The above expression is the Solow equation for the capital-output ratio in the steady state. A similar procedure for estimating the initial capital-output ratio has been used by Klenow and Rodríguez-Clare (1997). We then obtain an estimate of the initial capital stock by multiplying the estimated $(K / Y)_{1950}$ by 1950 real GDP:

$K_{1950}=(K / Y)_{1950} \cdot \operatorname{rgdpl}_{1950} \cdot \operatorname{pop}_{1950}$.

Depreciation: Following Klenow and Rodríguez-Clare (1997) we set $\delta=0.05$. 
Appendix 3: Summary Statistics

\begin{tabular}{llccccc}
\hline \multicolumn{2}{l}{ The Data: 1960-2004 } & Mean & Median & Sd & Min & Max \\
& & & & & & \\
\hline Y & GDP per Capita (rgdpl) & 2440 & 1454 & 2409 & 354 & 16421 \\
K & Capital per Capita & 3556 & 2033 & 3941 & 301 & 26000 \\
Ly & Ln(GDP per Capita) & 7.48 & 7.28 & 0.75 & 5.87 & 9.71 \\
Lk & Ln(Capital per capita) & 7.67 & 7.62 & 1.00 & 5.71 & 10.17 \\
IY & Ln(GDP) & 22.81 & 22.79 & 1.16 & 19.95 & 26.73 \\
lK & Ln (Capital) & 23.01 & 22.95 & 1.24 & 20.00 & 27.03 \\
Yr_sch (a) & Years of schooling & 2.91 & 2.56 & 1.91 & 0.19 & 8.84 \\
Yr_sch_pri & Years of primary schooling & 2.23 & 1.97 & 1.35 & 0.17 & 5.96 \\
Yr_sch_sec & Years of secondary schooling & 0.65 & 0.38 & 0.67 & 0.01 & 3.13 \\
Yr_sch_ter & Years of tertiary schooling & 0.03 & 0.02 & 0.04 & 0.00 & 0.31 \\
& Number of observations = 280 & & & & &
\end{tabular}

The Data: 2000-2004 (the final period of the five year averages for the PENN 6.3 World Tables and 2000 for the education data)

\begin{tabular}{llrrrrr}
\hline Y & GDP per Capita (rgdpl) & 2859 & 1546 & 3406 & 354 & 16421 \\
K & Capital per Capita & 4337 & 1933 & 5684 & 462 & 26000 \\
Ly & Ln(GDP per Capita) & 7.51 & 7.34 & 0.90 & 5.87 & 9.71 \\
Lk & Ln(Capital per capita) & 7.76 & 7.57 & 1.08 & 6.14 & 10.17 \\
IY & Ln(GDP) & 23.35 & 23.25 & 1.12 & 20.92 & 26.73 \\
lK & Ln (Capital) & 23.60 & 23.36 & 1.09 & 21.55 & 27.03 \\
Yr_sch & Years of schooling & 4.60 & 4.27 & 2.08 & 1.05 & 8.84 \\
Yr_sch_pri & Years of primary schooling & 3.36 & 3.40 & 1.44 & 0.93 & 5.85 \\
Yr_sch_sec & Years of secondary schooling & 1.18 & 1.00 & 0.82 & 0.11 & 3.13 \\
Yr_sch_ter & Years of tertiary schooling & 0.06 & 0.05 & 0.06 & 0.01 & 0.31
\end{tabular}

The Data: 1960-2004. These growth rates refer to the averages across the five year periods.

\begin{tabular}{lllllll}
\hline d_Yr_sch & Change in Years of Schooling & 0.40 & 0.33 & 0.32 & -0.61 & 2.19 \\
d_Yr_sch_pri & Change in Years of Schooling & 0.27 & 0.25 & 0.20 & -0.60 & 1.22 \\
d_Yr_sch_sec & Change in Years of Schooling & 0.12 & 0.08 & 0.15 & -0.22 & 0.92 \\
d_Yr_sch_ter & Change in Years of Schooling & 0.01 & 0.00 & 0.01 & -0.04 & 0.07 \\
d_ly & Change in Ln(GDP per Capita) & 0.03 & 0.03 & 0.15 & -0.53 & 0.57 \\
d_lk & Change in Ln(Capital per Capita) & 0.04 & 0.02 & 0.16 & -0.45 & 0.70 \\
& Number of observations = 257 & & & & &
\end{tabular}

All the years of schooling variables refer to the average levels of schooling of the population aged over 15.

For the GDP and capital variables the data is five year averages over the period 1960 to 2004. The data is from the PENN World Tables 6.3, Heston, Summers and Aten (2009) and is in constant international 2005 US\$ prices. 